\title{
Invitro Screening of Antifungal Activity of Rhizospheric Bacteria and Possible Role of Chitinase in Antifungal Activity
}

\author{
Hari K. Devkota ${ }^{1}$, Bijaya L. Maharjan ${ }^{1}$, Bikash Baral ${ }^{2}$, \\ Anjana Singh ${ }^{1}$, Kayo D. Yami ${ }^{2}$ \\ ${ }^{1}$ Central Department of Microbiology, Tribhuvan Univerity, Kirtipur, Kathmandu \\ ${ }^{2}$ Nepal Academy of Science and Technology, Khumaltar, Lalitpur \\ e-mail: hkdevkota@yahoo.com
}

\begin{abstract}
The use of biocontrol agents is becoming an increasingly important alternative to chemical crop protection against weeds, insects and plant diseases in the field of agriculture. The success of biocontrol and yield increase depends on the nature of antagonistic properties and mechanisms of action of the biocontrol agent against the phytopathogens. In this study, 103 macroscopically different bacterial isolates (62 from Kirtipur and 41 from Khumaltar) from 21 different rhizosphere soil samples (11 from Kirtipur and 10 from Khumaltar) were screened for antagonism against five fungal phytopathogens, viz, Fusarium oxysporum, Alternaria solani, Sclerotium rolfsii, Exserohilum turcicum and Phytophthora infestans by dual culture technique on Potato dextrose agar. Out of 18 different active isolates two of them showed the chitinolytic potential and the most active fungal antagonist was identified as Bacillus subtilis on the basis of colonial, morphological, physiological and biochemical characteristics based on Bergey's Manual of systemic bacteriology. The isolate produced maximum chitinase in colloidal chitin broth at $\mathrm{pH} 7$ and temperature $37^{\circ} \mathrm{C}$ after four days of inoculation. The corresponding culture filtrate supposed to contain chitinase showed maximum \% inhibition of 53.29\% with Fusarium oxysporum and no inhibition to Phytophthora infestans in agar well diffusion assay. Furthermore, chitinase was best fractionated at $40 \%$ ammonium sulphate salt fractionation which has almost similar inhibition potential as the crude culture filtrate. The $40 \%$ salt fraction of the enzyme showed the maximum chitinolytic potential at $\mathrm{pH} 8$ and temperature $40^{\circ} \mathrm{C}$. Among the phytopathogens tested, sensitivity of Bacillus subtilis to fungi containing chitin on their cell wall demonstrates the possible role of chitinase in the antifungal activity.
\end{abstract}

Key words: biocontrol, chitinase, Bacillus subtilis, phytopathogenes

\section{Introduction}

Increased public health concern about the accumulation of pesticide residue in the biosphere and the development of resistance among pathogens against conventional antibiotics has led scientists towards the development of alternative strategies for plant diseases suppression. Many countries in the 
world today are considering biological control as the best alternative to chemicals of plant diseases and pests (Suto et al. 2004). Biological control using microorganisms is largely based on the negative interactions among the microbial population. Biological control offers a specific activity against the targeted pathogens combined with the ability to stay as the non-dominant species while maintaining its effectiveness in an ecosystem with low cost of mass production (Shoda 2000).

The complexity of the rhizosphere ecosystem makes biological control of root pathogens by introduced bacteria a challenge. However, the endospore forming trait of Bacillus sp. made them suitable candidates for the biological control of plant diseases. The disease incidence of soil-borne fungus, Alternaria solani that causes the alternaria leaf spot disease of mustard was suppressed by $B$. subtilis strain UK-9 with reduced spore germination of leaves and it also demonstrated the plant growth promoting ability (Sharma \& Sharma, 2008). About 68\% disease suppression fusarium root rot caused by Fusarium oxysporum was found with B. subtilis (Ahmed et al. 2007). Paenibacillium sp. HKA-15 and B. Subtilis HKA-121 were found to be most potential candidates in the biocontrol of charcoal rot caused by $S$. rolfsii in soyabean (Senthilkumar et al. 2009). The B. subtilis AP-420 produced extracellular non volatile and diffusible metabolites which inhibited Exserohilum turcicum mycelia growth and conidial germination (Reis et al. 1994).

Viterbo et al. (2002) pointed out the two general mechanisms for the biological control. A direct effect includes competition for nutrition and space production of antibiotics and lytic enzymes, parasitism and indirect effect includes all those aspects that produce morphological and biochemical changes in the host plant. Among the various lytic enzymes chitinases are constituents of several bacterial species; some of the best known include the Bacillus, Serratia, Vibrio, Aeromonas and Streptomyces. The outer cell wall of phytopathogens which is composed of chitin is the primary action site of the chitinases. Therefore, formulations based on the chitinases offer potential biocontrol agent. Besides the ability to attack the fungal cell wall directly, chitinase release oligo-N- acetyl glucosamines that functions as the elicitors for the activation of defense-related responses in plants (Ren West., 1992). The chitinases of Bacillius origin are characterized by their activity across wide range of $\mathrm{pH}$ values of $4.0-8.5$ and temperature optimum ranges from $20-50^{\circ} \mathrm{C}$ (Bendt et al. 2001).

The purpose of this study is to examine the ability of various rhizobacteria isolated from rhizosphere to exert antagonistic effect on some phytopathogenic fungi, Alternaria solani, Fusarium proliferatum, Sclerotium rolfsii, Exherohilum turticum and Phytophthora infestans and to elucidate the inhibitory potential attributed to chitinase production by the active rhizobacterial isolates.

\section{Methodology}

The experiment was conducted at the Biotechnology Laboratory of Nepal Academy of Science and Technology (NAST).

\section{Isolation and purification of rhizospheric bacteria}

Twenty one different soil samples were collected from two different sites i.e., from the cultivated land from Kirtipur (11 samples) and Khumaltar (10 samples), from the rhizosphere of the Brassica campestris. Bacteria were isolated from different rhizosphere soil samples by pour plate technique. The root of Brassica campestris was dipped in the test tube containing ten $\mathrm{ml}$ of the sterile distilled water and shaken in the vortex to suspend the entire rhizospheric flora in the suspension. The serial dilution of the suspension was made by tenfold dilution method (Nomura \& Ohara, 1969), to obtain the suitable amount of dilution. Then $1 \mathrm{ml}$ of the suspension was kept to the centre of the 
sterile petri plates by sterile pipette. Then the sterile nutrient agar at $45^{\circ} \mathrm{C}$ was poured over the suspension. Then the plates were rotated for the uniform distribution of the organisms. Then the agar was allowed to solidify before incubation at $30^{\circ} \mathrm{C}$ for 24 hours. The bacterial colonies on the nutrient agar were simply differentiated from other actinomycetes and fungal colonies based on the colony characteristics. Then the isolates from Kirtipur soil samples were coded as $\mathrm{RBa}$ followed by the number and the isolates from the Satdobato were coded as RBA followed by the sample number. Then the isolated distinct colonies were sub-cultured on the dried nutrient agar plates until the pure culture were obtained.

\section{Isolation of the phytopathogenic fungi}

For the isolation of the phytopathogenic fungi, the diseased plant parts were obtained from Nepal Agricultural Research Council (NARC) plant pathology division. The phytopathogenic fungal organisms were isolated from the suspected plant parts. Several small sections of 5 to $10 \mathrm{~mm}$ square were cut from the margin of the infected lesions so that they contain both the diseased and healthy looking tissue. These were placed in the surface sterilizing agent. After about 10-15 seconds, the sections were taken aseptically one by one. These sections were then washed with sterile distilled water and were placed in the water agar. The inoculated media plates were incubated at $25^{\circ} \mathrm{C}$ for 5 days. Then the developed organisms were observed microscopically and the desired colonies were transferred to the Potato Dextrose Agar (PDA). The cultural characteristics and microscopic observation of the isolated organisms were done for the identification of the isolated organisms.

\section{Primary screening for antagonism}

The antifungal activity of the isolated bacteria was determined by dual culture method with slight modification in PDA (Alippi \& Monaco. 1994) against the test phytopathogens: Fusarium oxysporum, Alternaria solani, Phytophthora infestans, Sclerotium rolfsii and Exserohilum turcicum.

\section{Screening for chitinolytic activity}

The active isolates showing inhibition to at least one of the test phytopathogens were screened for their chitinolytic potential. For the determination of the chitinolytic activity the active bacterial culture were point inoculated at $30^{\circ} \mathrm{C}$ for 5 days. For the visualization of the chitinolytic activity the agar plates were flooded with $0.1 \%$ congo red solution for $15-30$ minutes. The visualization was further enhanced by washing the unbound congo red by $1 \% \mathrm{NaCl}$ solution.

\section{Characterization of the active isolates}

The bacterial isolate showing higher antifungal activity and higher chitinolytic activity was characterized by using different morphological, physiological and biochemical tests as described in the category II of the Bergey's manual of Systemic bacteriology.

\section{Secondary screening}

The fermentation process was carried out in the $200 \mathrm{ml}$ Erylenmeyer flask containing sterilized colloidal chitin broth. The fresh culture of the isolate was inoculated in the $50 \mathrm{ml}$ of the chitin broth medium and shaken in the water bath shaker for 7 days at $37^{\circ} \mathrm{C}$ at the rate of 150 revolutions per minute (rpm). For the secondary screening process, the culture broths after fermentation were centrifuge 10,000 rpm for 15 minutes at $4^{\circ} \mathrm{C}$ in sterile condition. The culture supernatants were further made cell free by passing through the

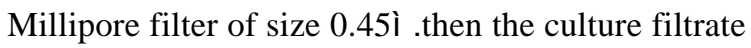
was used to assay the antifungal activity against the test phytopathogens: Fusarium proliferatum, Alterneria solani, Phytophthora infestans, Sclerotinum rolfsii, and Exserohilum turcicum individually by agar well diffusion assay in PDA as described by Walker et al. (1998). 


\section{Preparation of concentrated enzyme solution by acetone bath method}

Concentrated chitinase enzyme solution was prepared according to the method described by Fuji and Kume (1991). The filtrate solution was precipitated by adding two volumes of ice cold acetone (kept in defreeze for overnight) to one volume of the supernatant solution. The chitinase enzyme was precipitated as white at the bottom of the container. The clear supernatant was discarded and the white precipitate was dissolved in the minimum amount of phosphate buffer ( $\mathrm{pH}$ 7.2). Then the solution was centrifuged in the microfuge tube at the speed $15000 \mathrm{rpm}$ at $4^{\circ} \mathrm{C}$ for 15 minutes. Then the supernatant was discarded and the precipitate was dissolved in the minimum amount of phosphate buffer i.e., 50ill.Then the solution was subjected to salt fractionation.

\section{Ammonium sulphate fractionation of the acetone concentrated enzyme solution}

The acetone concentrated enzyme solution was subjected to the ammonium sulphate fractionation. Ammonium sulphate fractionation was carried out at $40 \%, 60 \%$ and $80 \%$ percentage saturation. For each percentage saturation chosen, the $\left(\mathrm{NH}_{4}\right)_{2} \mathrm{SO}_{4}$ salt was added slowly while stirring and the mixture left at $4^{\circ} \mathrm{C}$ for an hour before centrifuging at 15000 rpm for 15 minutes. After centrifugation for $40 \%$ saturation fraction, the supernatant was used for further fractionation whereas the pellet was dissolved in minimum amount of phosphate buffer solution and was further used for analysis. Similar procedure was carried out for the $60 \%$ saturation fraction and $80 \%$ saturation fraction from the supernatant obtained from the $40 \%$ and $60 \%$ saturation fraction respectively.

\section{Determination of antifungal potential of the putative enzyme}

The antifungal potential of the four different fraction viz, acetone concentrated fraction, $40 \%, 60 \%$ and $80 \%$ ammonium sulphate saturation fraction was tested by agar well diffusion method Walker et al. (1998) and percentage inhibition of different fraction was determined.

\section{Determination of optimum temperature and pH for chitinolysis}

Agar well diffusion method was used for the determination of optimum temperature and $\mathrm{pH}$. For the determination of optimum temperature for chitinolysis, the different enzyme fractions were incubated at different range of temperatures $\left(30^{\circ} \mathrm{C}, 40^{\circ} \mathrm{C}, 50^{\circ} \mathrm{C}, 60^{\circ} \mathrm{C}\right.$, $70^{\circ} \mathrm{C}$ and $80^{\circ} \mathrm{C}$ ) for 30 minutes. Then different fractions incubated at different temperatures were placed in the wells of the colloidal chitin agar plates. The enzyme fraction were allowed to diffuse and then incubated at $37^{\circ} \mathrm{C}$ for $24-48$ hours. Then the zone of hydrolysis was observed after staining with $0.1 \%$ congo red and destained with $5 \% \mathrm{NaCl}$ solution. Similarly, for the determination of optimum $\mathrm{pH}$ for the activity of chitinase, different colloidal chitin agar plates ranging from $\mathrm{pH} 4$ to $\mathrm{pH} 10$ were prepared and different fraction of the salt fractionated enzyme were placed in the wells. Then the plates were incubated at $37^{\circ} \mathrm{C}$ for $24-48$ hours and zone of hydrolysis was observed after staining and de-staining with $0.1 \%$ congo red and $5 \% \mathrm{NaCl}$ respectively.

\section{Results and Discussion In-vitro screening for antagonism}

All together 103 different microscopically different colonies were isolated from 21 different rhizospheric soil samples from the cultivated land of Khumaltar and Kirtipur. In total, 62 colonies were isolated from the 11 soil samples of Kirtipur and 41 from 10 soil samples of Khumaltar. These isolates were taken for the in-vitro screening for antagonism against the test phytopathogens; F. oxysporum, A. solani, S. rolfsii, $P$. infestans and E. turcicum by dual culture technique. It showed that 18 isolates (RBA1, RBA2, RBA5(i), RBA5(ii), RBA6, RBA8, RBA9, RBA10, RBa1, RBa2(i), RBa2(ii), RBa2(iii), RBa4, RBa5, RBa7, RBa10(i), RBa10(ii), RBa11) showed antagonism to at least one of the test phytopathogens. Two of the potent rhizobacterial antagonists RBA6 and RBa11 showed the chitinolytic potential. The isolate RBa11 with higher antagonism potential and higher chitinolytic potential was identified on the basis of the morphological and biochemical characterstics in accordance with Bergey’s manual as Bacillus subtilis. 
Hari K. Devkota et al./Invitro screening .......

Table 1. Identification chart for the isolate RBa11

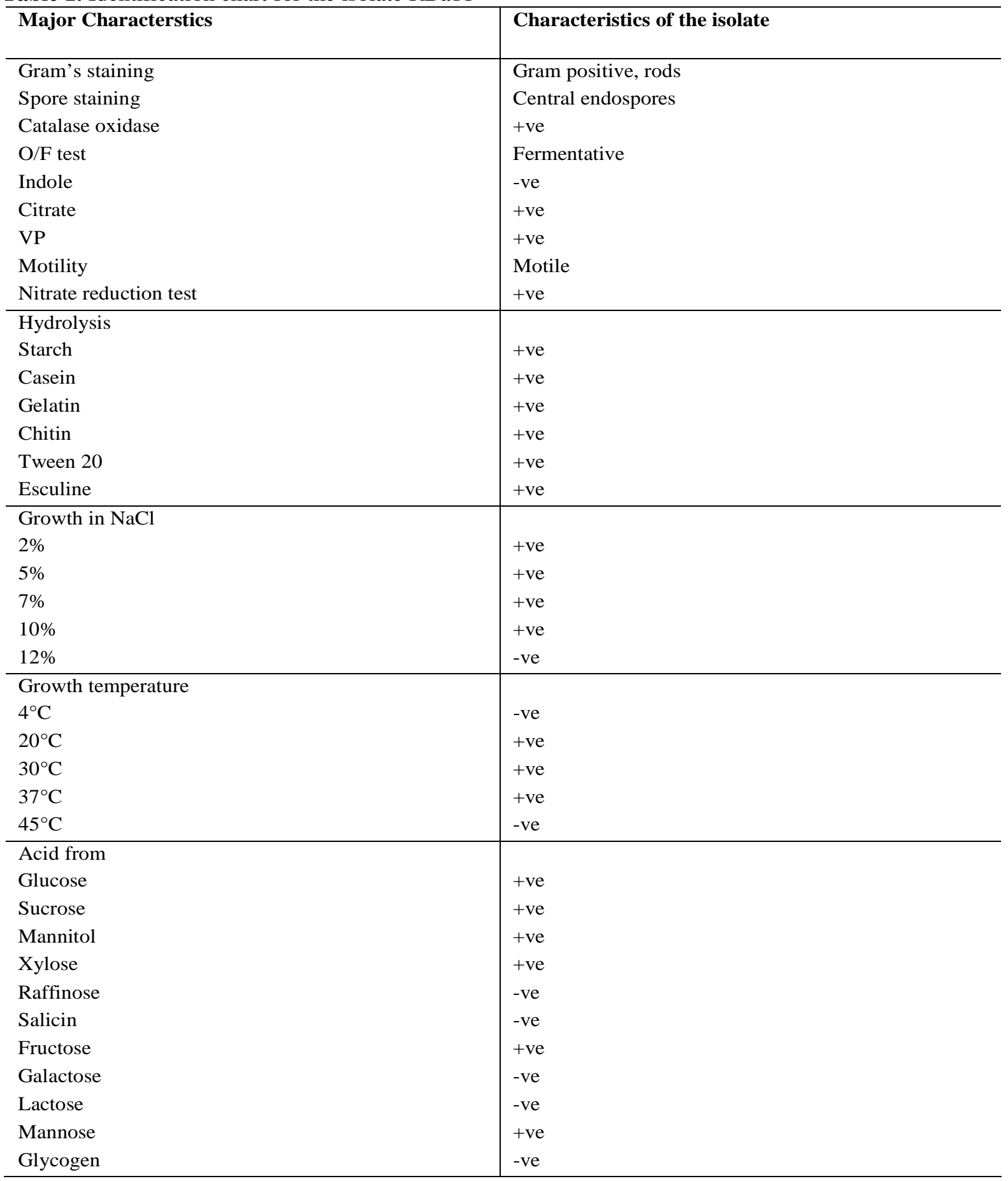




\section{Chitinase production}

Chitinase production was carried out using the best isolate. chitinase was produced after 48 hours onwards but the optimum production was after 96 hours. After 96 hours the chitinase production was constant but after 120 hours it was decreased. The production of chitinase is shown by the zone of hydrolysis at different incubation period of the fermentation at $37^{\circ} \mathrm{C}$ as shown in the table 1 below.

Table 2: Zone of hydrolysis in chitin agar

\begin{tabular}{c|c|c}
\hline S No. & Incubation period & Zone of hydrolysis (in mm) \\
\hline 1 & 24 & 6 \\
2 & 48 & 8 \\
3 & 72 & 12.5 \\
4 & 96 & 16 \\
5 & 120 & 13 \\
6 & 144 & 11.5 \\
\hline
\end{tabular}

Note: diameter of the well is $6 \mathrm{~mm}$.

\section{Inhibition of the phytopathogens}

The inhibition of the growth of test phytopathogens in agar well diffusion technique was expressed in terms of percentage inhibition. The crude culture filtrate showed the maximum inhibition after 96 hours of fermentation at $37^{\circ} \mathrm{C}$ with the maximum inhibition of Fusarium oxysporum upto $53.29 \%$ and no inhibition of the Phytophthora infestans.
The percentage inhibition is calculated as $(R-r) / R \times 100$, where $R$ is mycelial growth away from well filled with culture filtrate (the maximum growth of the fungal mycelia), $r$ is mycelial growth towards the well filled with the culture filtrate. Different inhibition pattern of the culture filtrate is given in the table 2 below. The crude culture filtrate showed the highest percentage inhibition to Fusarium oxysporum (53.29\%) at 96 hours of incubation, lowest to Exserohilum turcicum and no inhibition to Phytophthora infestans.

Table 3. Inhibition \% of the test phytopathogens in the presence of probable Bacillus subtilis culture filtrate in colloidal chitin agar.

\begin{tabular}{c|c|c|c|c|c|c}
\hline SN & \multirow{2}{*}{$\begin{array}{c}\text { Incubation } \\
\text { period }\end{array}$} & \multicolumn{6}{|c}{ Percentage inhibition (in \%) } \\
\cline { 3 - 6 } & & $\begin{array}{c}\text { Fusarium } \\
\text { oxysporum }\end{array}$ & $\begin{array}{c}\text { Alternaria } \\
\text { solani }\end{array}$ & $\begin{array}{c}\text { Sclerotium } \\
\text { rolfsii }\end{array}$ & $\begin{array}{c}\text { Exserohilum } \\
\text { turcicum }\end{array}$ & $\begin{array}{c}\text { Phytophthora } \\
\text { infestans }\end{array}$ \\
\hline 1 & 24 & - & - & - & - & - \\
2 & 48 & 13.6 & 17.64 & 9.67 & 8.3 & - \\
3 & 72 & 43.18 & 20.58 & 25.80 & 12.5 & - \\
4 & 96 & 53.29 & 41.23 & 28.41 & 15.24 & - \\
5 & 120 & 36.36 & 29.41 & 27.41 & 12.5 & - \\
6 & 144 & 15.90 & 26.47 & 16.12 & 12.5 & - \\
\hline
\end{tabular}


Hari K. Devkota et al./Invitro screening .......

This result revealed that the inhibition activity was due to the chitinolytic potential. The true fungi those belonging to the group Asco, Phyco, Basidio and Duteromycetes contain chitin as the major cell wall component. However, the phytopathogen Phytophthora infestans belongs to the group Oomycota which does not have chitin in its cell wall. So they are resistant to the chitinase action. The other test phytopathogens showed sensitivity to different percentage towards the crude culture filtrate. During the primary screening process the partial inhibition of Phytophthora infestans may be due to the production of some other antifungal metabolites that are not produced during the fermentation in the chitinase minimal medium. Furthermore, the complete inhibition of other test phytopathogens in the primary screening process may be due to other antifungal metabolite in addition to the chitinases.

Table 4. Inhibition $\%$ of test phytopathogens by different protein fraction

\begin{tabular}{cc|cc|ccc}
\multirow{2}{*}{ SN } & $\begin{array}{c}\text { Protein } \\
\text { fraction }\end{array}$ & \multicolumn{5}{|c}{ Percentage inhibition (in \%) } \\
\cline { 3 - 7 } & & $\begin{array}{c}\text { Fuscrium } \\
\text { oxysporum }\end{array}$ & $\begin{array}{c}\text { Alternaria } \\
\text { solani }\end{array}$ & $\begin{array}{c}\text { Sclerotium } \\
\text { rolfsii }\end{array}$ & $\begin{array}{c}\text { Exserohilum } \\
\text { tworcicum }\end{array}$ & $\begin{array}{c}\text { Phytophthora } \\
\text { infestans }\end{array}$ \\
\hline 1 & Acetone & 59.09 & 54.54 & 30.60 & 16.66 & - \\
2 & $40 \%$ & 58.17 & 55.87 & 32.45 & 18.64 & - \\
3 & $60 \%$ & 20.28 & 29.85 & 22.20 & 9.3 & - \\
4 & $80 \%$ & 18.88 & 22.34 & 18.34 & 9.3 & - \\
\hline
\end{tabular}

The result showed the maximum zone of hydrolysis by $40 \%$ fraction followed by acetone precipitated fraction. This result showed the maximum chitinase was precipitated at $40 \%$ salt concentration. This result was in co-relation with the result obtained by Chen et al. (2004) during the two step purification of the Bacillus circulans chitinase A expressed in E. coli periplasm. Similarly, the putative chitinase band ( $88 \mathrm{kDa}$ ) with $40 \%$ ammonium sulphate fractionation gave the highest yield of the desired protein. Thus chitinase was better obtained by 40\% ammonium sulphate fractionation.

\section{Determination of optimum pH and temperature for chitinolysis}

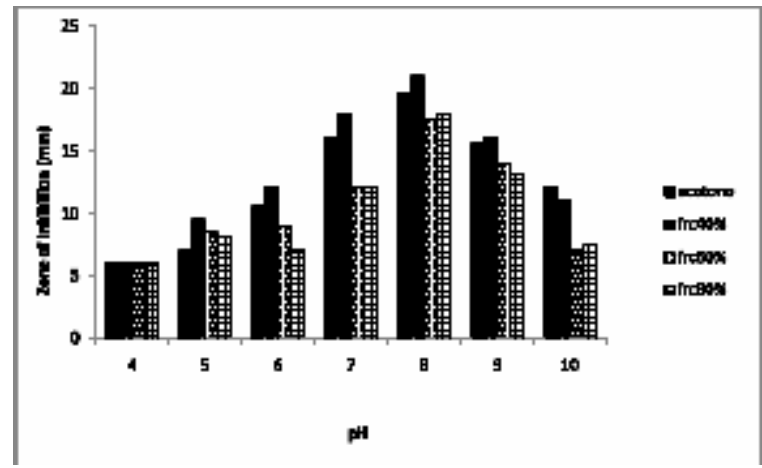

Fig. 1. Comparative chart of zone of hydrolysis at different $\mathrm{pH}$

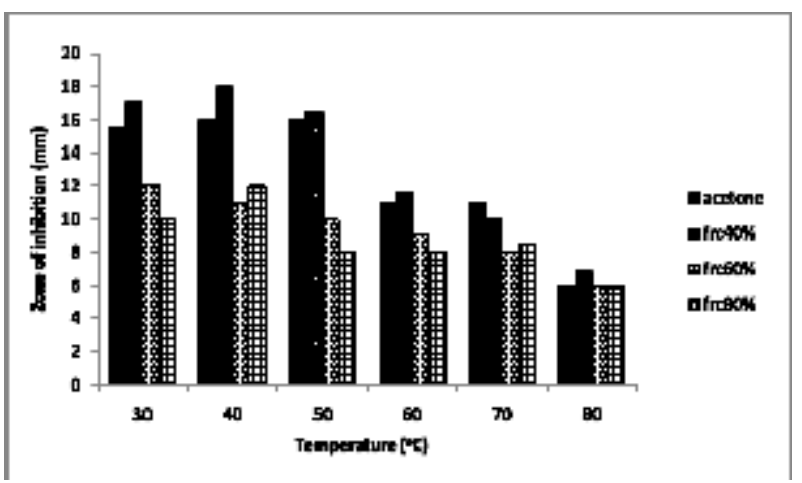

Fig. 2. Comparative chart of zone of hydrolysis at different temperature

The above figure shows that the enzyme chitinase has its optimum activity at $\mathrm{pH} 8$ and temperature $40^{\circ} \mathrm{C}$ as shown by the zone of hydrolysis in the colloidal chitin agar. The temperature and the $\mathrm{pH}$ are certainly important factors that determine the extent of hydrolysis of the chitin by chitinases. Chitinases are characterized by their activity across wide range of $\mathrm{pH}$ values of 4.0 -8.5 and temperature optimum ranges from $20-50^{\circ} \mathrm{C}$ (Bendt et al. 2001). In our experiment the putative chitinase showed its optimum hydrolysis potential at $\mathrm{pH} 8.0$ and temperature $40^{\circ} \mathrm{C}$. The activity range of the chitinase of bacteria was always higher than that of the chitinase isolated from the fungi. The 
finding was similar to that of the Bhushan and Hoondal (1998), according to them the optimum activity of the chitinase in Bacillus sp.BG-11 occurred at pH of 8.5 while Frandberg and Schnurer (1994) observed the highest chitinolytic activity at pH 8.0.

The result obtained from the study has shown that the rhizospheric isolate, $B$. subtilis, was active against 4 test pathogens during in-vitro screening experiment except $P$. infestans. The chitinolytic potential of the isolate was responsible for the inhibition of the test pathogens and the probable chitinase has optimum activity at $40^{\circ} \mathrm{C}$ and at $\mathrm{pH}$ 8.0. However, more detailed and specialized studies of field trials, interaction with indigenous soil microorganisms and application methods of the agent, are needed for the effective and secure biocontrol.

\section{Acknowlegdements}

The authors thank all the staff of NAST for their help during the entire research period. Authors would like to express the gratefulness to Nepal Agricultural Research Council (NARC), Plant Pathology Division for providing the test pathogens.

\section{Feferences}

Ahmed, I.H., N. Lubuschagne and L. Korsten. 2007. Screening rhizobacteria for biological control of Fusarium root and crown rot of Sorghum in Ethiopia. Biological control 40(1): 97-106.

Alippi, A. and C. Monaco. 1994. Antagonismo in vitro de species de Bacillus contra Sclerotium rolfsii y Fusarium solani. Revista de la Facultad de Agronomia, La Plata 70: 91-95.

Bendt, A., H. Huller., U. Kamme., E. Helmke, and T. Schweder 2001. Cloning, expression and characterization of a chitinase gene from the Antarctic psychrotolerant bacterium Vibrio sp. strain Fi:7. Extremophiles, 5: 119-126.

Bhushan, B. and G.S.Hoondal. 1998. Isolation, purification and properties of a thermostable chitinase from an alkalophilic Bacillus sp. BG - 11. Biotechnology letters. 20(2):157.
Chen, C. T., C. J. Huang., Y. H.Wang, and C.Y. Chen. 2004. Two step purification of Bacillus circulans chitinase A, expressed in E. coli periplasm. Protein expression and purification 37(1):27-31.

Frandberg, E. and J. Schnurer. 1994. Chitinolytic properties of Bacillus pabuli K1. J. Appl Bacteriol. 76: 361-367.

Fuji, Y. and S. Kume. 1991. Characteristics of a highly thermostable neutral protease produced from $B$. stearothermophilus. World journal of Microbiology and Biotechnology 7:12-16.

Nomura, N. and Y. Ohara. 1969. Journal of fermentation technology 47: 463-469.

Reis, A., N.S.S.Silveria., S. J. P. Michereff., G. F. A Pereira, and R. L. R. Mariano. 1994. Bacillus subtilis as potential biocontrol agent of the northern leaf blight of corn. Rev. Microbial, 25(4): 255-260.

Ren, Y. and C. A. West. 1992. Elicitation of diterpene biosynthesis in rice (Oryza sativa L.) by chitin. Plant Physiol. 99:1169-1178.

Senthilkumar. M., V. Govindasamy., Y. K. Lee., K. Swarnalakshmi, and K. Annapurna. 2009. Biocontrol potential of soyabean endophytes against charcoal rot fungus Rhizoctonia bataticola. Curr Microbiol. 58:288-293.

Sharma, N. and S. Sharma. 2008. Control of foliar diseases of mustard by Bacillus from reclaimed soil. Microbiological research, 163(4): 408-413.

Shoda, M. 2000. Review, Biological control of plant diseases. Journal of Bioscience and Bioengineering 89:515-52.

Suto, G. I., O. S. Correa., M. S. Montecchia., N. L. Keber., N. L. Pucheu., M. Bachur, and Garcia, A.F. 2004. Genetic and functional characterization of Bacillus sp. strain exerting surfactin and antifungal metabolites partially identified as Iturin like compounds. Journal of Applied Microbiology 97: 1247-1256.

Viterbo, A., O. Ramot., L. Chernin., I. Chet. 2002. Significance of lytic enzymes from Trichoderma sp. in the biocontrol of fungal plant pathogens. Anton. Leeuw. 81:549-556.

Walker, R., A. A. Powell, and B. Seddon. 1998. Bacillus isolates from the spermosphere of peas and dwarf French beans with antifungal activity against Botrytis cinerea and Pythium species. Journal of Applied Microbiology 84(5): 791-801. 